\title{
Neonatal unplanned extubations: an unsolved safety issue
}

\author{
Diana K. Segura-Ramírez, Sara Fernández-Castiñeira, Diana C. Gualotuña-Maigua, Silvia Martín-Ramos, \\ Sonia Lareu-Vidal, and Gonzalo Solís-Sánchez* \\ Servicio de Neonatología del Área de Gestión Clínica de Pediatría, Hospital Universitario Central de Asturias, Oviedo, España
}

\begin{abstract}
Background: Unplanned extubations are safety events relatively frequent in the neonatal intensive care units (NICU). This study aimed to describe the frequency and characteristics of unplanned extubations in a NICU. Methods: We conducted a retrospective observational study of unplanned extubations in the NICU of a tertiary regional referral hospital. We reviewed medical records for data collection and performed the statistical analysis, comparing the cases of unplanned extubations with those in which it did not occur among all the cases that received intubation and invasive neonatal mechanical ventilation. Results: A total of 958 newborns were admitted to the NICU, of which 174 required assistance with invasive mechanical ventilation (18.1\%) and 28 experienced unplanned extubations (16.1\%): 25 patients with one episode, one with two episodes, and two with three episodes. The rate was 2.93 unplanned extubations for every 100 days of invasive mechanical ventilation in 5 years, with a significant decrease in the last three years $(p=0.0158)$. We found a statistically significant correlation between a weight < $1500 \mathrm{~g}$ and unplanned extubation in the multivariate analysis, although sedation appears to affect its interaction. Conclusions: Unplanned extubations are a relatively frequent problem, although with a tendency to decrease in recent years. The weight of the patients at birth and sedation during ventilation are important factors in this safety problem.
\end{abstract}

Keywords: Unplanned extubation. Newborn. Invasive mechanical ventilation. Healthcare safety.

\section{Extubaciones neonatales no programadas: un problema de seguridad no resuelto}

\section{Resumen}

Introducción: La extubación no programada es un evento de seguridad relativamente frecuente en las unidades de cuidados intensivos neonatales (UCIN). El objetivo de este estudio fue conocer la frecuencia y las características de las extubaciones no programadas en una UCIN. Métodos: Se realizó un estudio observacional retrospectivo de las extubaciones no programadas en la UCIN de un hospital regional de referencia de tercer nivel. Se revisaron las historias clínicas y se realizó el análisis estadístico de los datos, comparando los casos de extubación no programada con aquellos en los que no sucedió entre todos los pacientes que recibieron intubación y ventilación mecánica invasiva neonatal. Resultados: Ingresaron en la UCIN 958 neonatos, de los cuales 174 precisaron asistencia con ventilación mecánica invasiva (18.1\%) y 28 tuvieron una extubación no programada (16.1\%). De estos, 25 presentaron un episodio, uno presentó dos episodios y dos presentaron tres episodios de extubación no programada. La tasa fue de 2.93 extubaciones no programadas por cada 100 días de ventilación mecánica invasiva en 5 años, con una importante disminución en los últimos 3 años $(p=0.0158)$. El peso < 1500 g

\footnotetext{
Correspondence:

*Gonzalo Solís Sánchez

E-mail: gsolis@ telefonica.net

Available online: 08-06-2021

Bol Med Hosp Infant Mex. 2021;78(4):259-264

www.bmhim.com

1665-1146/@ 2020 Hospital Infantil de México Federico Gómez. Published by Permanyer. This is an open access article under the CC BY-NC-ND license (http://creativecommons.org/licenses/by-nc-nd/4.0/).
} 
se relacionó con las extubaciones no programadas de forma estadísticamente significativa en el análisis multivariante, aunque la sedación aparece como un factor modificador de efecto a través de su interacción. Conclusiones: Las extubaciones no programadas son un problema relativamente frecuente, aunque con tendencia a disminuir en los últimos años. El peso de los pacientes al nacimiento y la sedación son factores importantes en este problema de seguridad.

Palabras clave: Extubación no programada. Recién nacido. Ventilación mecánica invasiva. Seguridad asistencial.

\section{Introduction}

Patient safety is one of the most critical aspects of healthcare. This statement has even more weight when it comes to critical neonatal patients. Therefore, the safety culture within neonatal services is essential for a high-quality neonatal practice'.

Intubation and ventilation of a neonate represent a high-risk situation due to many possible related consequences $^{2,3}$. Unplanned extubations (UEs) are a relatively frequent safety event in pediatric intensive care units (PICU) and neonatal intensive care units (NICU) and, as such, should be included in the quality lists of these services ${ }^{4,5}$. Although the incidence is highly variable, it can be estimated from 0.1 to 6.6 episodes per 100 ventilator days ${ }^{2}$.

We define an UE as removing the endotracheal tube from a ventilator-supported patient at any time other than the one deliberately planned for it. The removal is caused by the patient or medical or nursing staff action during a procedure ${ }^{6,7}$. Therefore, it is an undesired adverse event.

It is known that UEs are associated with poorer clinical outcomes and higher healthcare costs ${ }^{8}$. Therefore, further study of these adverse events will help to reduce their occurrence rates and prevent their incidence ${ }^{2,9}$. To know the frequency and the characteristics of the patients who experience UEs (gestational age, weight, sex, cause, and time of intubation, among others) in our NICU, we conducted a retrospective observational study. We consider that knowledge of these characteristics can improve the quality of care and patient safety.

\section{Methods}

We conducted a retrospective observational study of neonates who required invasive mechanical ventilation in the NICU of a tertiary, regional referral hospital between 1/1/2015 and 12/31/2019. Our center serves a population of 2000 newborns per year born and another 3000 newborns per year as a referral NICU.

We searched the hospital database and service records for all newborns admitted to the NICU who required invasive mechanical ventilation during their admission. We reviewed each one of the medical records of these cases and documented the most important variables. According to a primary or dependent variable, we formed two groups: those who underwent UEs and those who did not. General variables (sex, gestational age and birth weight, cause of ventilation, age at onset, days of ventilation, sedation during ventilation, days of NICU stay, mortality) were recorded in all cases. The characteristics of the episodes (day of the week of the event, work shift, time since intubation, and need for re-intubation) were also analyzed in UE cases.

We considered an UE as the event in which an intubated neonate was extubated without having planned this action. The extubation could be spontaneous or the consequence of a care maneuver. Data were obtained from the electronic medical records, where the episodes of UEs must be recorded. The same intubation and endotracheal tube fixation technique were maintained during the analyzed period.

Once data were extracted and registered anonymously, an initial descriptive statistical analysis was performed. Subsequently, data were compared and possible associations were sought between the groups and the recorded variables.

The absence of normality of most of the quantitative variables was verified (Kolmogorov-Smirnov test). Therefore, we decided to describe the quantitative variables with medians and interquartile ranges (IQR) and use non-parametric statistics in the comparisons. Qualitative variables were described with frequencies, and $\chi^{2}$ test was used for associations (Fisher's exact test if expected counts $<5$ ). Binary logistic regression (UE/no UE) was performed by entering the following variables into the model: birth weight $<1500 \mathrm{~g}$, sex, intubation time, gestational age $<32$ weeks, sedation, and cause of intubation. Stratification and MantelHaenszel odds ratio (OR) estimation were also used to test for interaction between variables. Statistical significance was kept at a probability of 0.05 .

Permission to perform the work was obtained from the PA Research Ethics Committee (application 20/18), and the principles of research ethics and confidentiality 
were followed according to the current international legislation.

All the manuscript authors participated in the study design, literature review, data collection, data analysis, and writing and reviewing the manuscript.

\section{Results}

During 5 years, 958 neonates were admitted to the NICU $(75.5 \%$ born in the hospital and $24.5 \%$ from other hospitals in the region), of whom 174 (91 males and 83 females) required invasive mechanical ventilation (18.1\%). These 174 patients were born with a median gestational age of 34 weeks (IQR 9) and a median birth weight of $1995 \mathrm{~g}$ (IQR 1953).

The median age at intubation was 0 days (IQR 1). In the first 24 hours of life, 123 cases (70.7\%) were intubated and 159 cases (91.4\%) in the first week of life. The reasons for mechanical ventilation were respiratory (acute respiratory failure) in 127 cases (73\%), surgical in 25 cases (14.4\%), and non-respiratory medical causes (cardiological and neurological) in 22 cases (12.6\%); $30.5 \%$ received sedation/analgesia during ventilation. The median ventilation time was 2 days (IQR 5); $17.8 \%$ died before discharge from the NICU. The total ventilation time of the series was 1125 days.

Of the 174 patients who were ventilated, 28 underwent an UE (16.1\%): 25 presented one UE episode, one presented two episodes, and two presented three episodes; in total, there were 33 episodes in 5 years. The median age at the time of the UE was 4 days (IQR 20), and the median ventilation time from the last intubation to the time of the UE was one day (IQR 5). Five cases received pharmacological sedation (15.2\%). Sixteen episodes (48.4\%) required re-intubation; twelve required immediate re-intubation. Three of the $28 \mathrm{UE}$ cases died before discharge from the NICU (10.7\%) (Table 1).

The UE rate over 5 years was 2.93 UE per 100 days of invasive mechanical ventilation. This rate has varied from 4.52 in 2016 to 0.52 in 2019 ( $p=0.0158)$ (Table 2). We found no statistically significant differences between UE rates by cause of ventilation $(p=0.480$ ) or by day of the week on which extubation occurred $(p=0.976)$ (Table 1).

In the univariate analysis, we found that birth weight $<1500 \mathrm{~g}$ [OR 3.1; 95\% confidence interval (Cl) 1.3-7. ${ }^{3}$ and gestational age < 32 weeks (OR 2.4; $95 \% \mathrm{Cl}$ 1.0-5.6) were significantly related to UEs (Table 3 ).

After performing a binary logistic regression with the forward LR method and introducing the gestational age, sex, birth weight $<1500 \mathrm{~g}$, gestational age $<32$ weeks,
Table 1. Characteristics of the episodes of unplanned extubations

\begin{tabular}{|c|c|}
\hline $\begin{array}{l}\text { Patients (n) } \\
\text { With } 1 \text { UE } \\
\text { With } 2 \text { UE } \\
\text { With } 3 \text { UE } \\
\text { Total }\end{array}$ & $\begin{array}{c}n \\
25 \\
1 \\
2 \\
33\end{array}$ \\
\hline $\begin{array}{l}\text { Age at the UE episode (days) } \\
\text { Median } \\
\text { Interquartile range }\end{array}$ & $\begin{array}{c}4 \\
20\end{array}$ \\
\hline $\begin{array}{l}\text { IMV days from intubation to UE } \\
\text { Median } \\
\text { Interquartile range }\end{array}$ & $\begin{array}{l}1 \\
5\end{array}$ \\
\hline $\begin{array}{l}\text { Shift } \\
\text { Morning } \\
\text { Afternoon } \\
\text { Evening }\end{array}$ & $\begin{array}{c}n(\%) \\
9(27.3 \%) \\
9(27.3 \%) \\
15(45.5 \%)\end{array}$ \\
\hline $\begin{array}{l}\text { Day of the week when UE occurred } \\
\text { Workday } \\
\text { UE rate per } 100 \text { working days } \\
\text { Holiday } \\
\text { UE rate per } 100 \text { holidays }\end{array}$ & $\begin{array}{l}n(\%) \\
23(69.7 \%) \\
2.86 \\
10(30.3 \%) \\
3.11\end{array}$ \\
\hline $\begin{array}{l}\text { Cause of invasive ventilation } \\
\text { Respiratory cause } \\
\text { UE rate per } 100 \text { days in "respiratory" group } \\
\text { Non-respiratory cause } \\
\text { UE rate per } 100 \text { days in "non-respiratory" group }\end{array}$ & $\begin{array}{c}n(\%) \\
29(87.8 \%) \\
3.16 \\
4(12.1 \%) \\
1.91\end{array}$ \\
\hline $\begin{array}{l}\text { Need for re-intubation } \\
\text { In the first } 24 \text { hours after UE } \\
\text { Beyond the first } 24 \text { hours after UE }\end{array}$ & $\begin{array}{c}12(36.3 \%) \\
4(12.1 \%)\end{array}$ \\
\hline
\end{tabular}

IMV, invasive mechanical ventilation; UE, unplanned extubation.

Table 2. Time course of unplanned extubations in the neonatal intensive care unit

\begin{tabular}{|l|c|c|c|c|}
\hline $\begin{array}{l}\text { Year of } \\
\text { study }\end{array}$ & $\begin{array}{c}\text { Number of } \\
\text { ventilated } \\
\text { neonates }\end{array}$ & $\begin{array}{c}\text { Days of } \\
\text { invasive } \\
\text { mechanical } \\
\text { ventilation }\end{array}$ & $\begin{array}{c}\text { Number } \\
\text { of UE }\end{array}$ & $\begin{array}{c}\text { UE rate } \\
\text { per 100 } \\
\text { ventilator } \\
\text { days }\end{array}$ \\
\hline 2015 & 39 & 389 & 15 & 3.85 \\
\hline 2016 & 39 & 221 & 10 & 4.52 \\
\hline 2017 & 34 & 157 & 3 & 1.91 \\
\hline 2018 & 35 & 168 & 4 & 2.38 \\
\hline 2019 & 27 & 190 & 1 & 0.52 \\
\hline Total & 174 & 1125 & 33 & 2.93 \\
\hline
\end{tabular}

$\chi^{2}$ for linear trend $(p=0.0158)$

UE, unplanned extubations.

receiving sedation during ventilation, and having been intubated for respiratory or non-respiratory causes into the model, only birth weight $<1500 \mathrm{~g}$ remained in the 
Table 3. Comparison of cases with or with no unplanned extubation

\begin{tabular}{|c|c|c|c|}
\hline Variables & Neonates with UE (28 cases) & Neonates with no UE (146 cases) & $p$-values \\
\hline $\begin{array}{l}\text { Gestational age at birth in weeks } \\
\text { Median } \\
\text { Interquartile range }\end{array}$ & $\begin{array}{l}29 \\
10\end{array}$ & $\begin{array}{c}35 \\
9\end{array}$ & $0.077^{*}$ \\
\hline $\begin{array}{l}\text { Type of case by gestational age } \\
<32 \text { weeks of gestation } \\
\geq 32 \text { weeks of gestation }\end{array}$ & $\begin{array}{l}17(60.8 \%) \\
11(59.2 \%)\end{array}$ & $\begin{array}{l}56(38.4 \%) \\
9061.6 \%)\end{array}$ & $\begin{array}{c}0.028^{* *} \\
\text { OR: } 2.4(95 \% \mathrm{Cl} 1.0-5.6)\end{array}$ \\
\hline $\begin{array}{l}\text { Birth weight } \\
\text { Median } \\
\text { Interquartile range }\end{array}$ & $\begin{array}{l}1390 \\
1915\end{array}$ & $\begin{array}{l}2117 \\
1958\end{array}$ & $0.086^{*}$ \\
\hline $\begin{array}{l}\text { Type of case by birth weight } \\
<1500 \mathrm{~g} \\
\geq 1500 \mathrm{~g}\end{array}$ & $\begin{array}{l}18(64.2 \%) \\
10(35.8 \%)\end{array}$ & $\begin{array}{l}53(36.3 \%) \\
93(63.7 \%)\end{array}$ & $\begin{array}{c}0.006^{* *} \\
\text { OR: } 3.1(95 \% \mathrm{Cl} 1.3-7.3)\end{array}$ \\
\hline $\begin{array}{l}\text { Sex } \\
\text { Male } \\
\text { Female }\end{array}$ & $\begin{array}{l}14(50 \%) \\
14(50 \%)\end{array}$ & $\begin{array}{l}77(53 \%) \\
69(47 \%)\end{array}$ & $\begin{array}{c}0.790^{* *} \\
\text { OR: } 0.8(95 \% \mathrm{Cl} 0.3-2.0)\end{array}$ \\
\hline $\begin{array}{l}\text { Cause of intubation } \\
\text { Respiratory } \\
\text { Non-respiratory }\end{array}$ & $\begin{array}{c}24(85.7 \%) \\
4(14.3 \%)\end{array}$ & $\begin{array}{l}103(70.5 \%) \\
43(29.5 \%)\end{array}$ & $\begin{array}{c}0.098^{* *} \\
\text { OR } 2.5(95 \% \mathrm{Cl} 0.8-7.6)\end{array}$ \\
\hline $\begin{array}{l}\text { Sedation/analgesia } \\
\text { Yes } \\
\text { No }\end{array}$ & $\begin{array}{c}5(17.9 \%) \\
23(82.1 \%)\end{array}$ & $\begin{array}{l}48(32.9 \%) \\
98(67.1 \%)\end{array}$ & $\begin{array}{c}0.109^{* *} \\
\text { OR: } 0.4(95 \% \mathrm{Cl} 0.1-1.2)\end{array}$ \\
\hline $\begin{array}{l}\text { Age at first intubation (days) } \\
\text { Median } \\
\text { Interquartile range }\end{array}$ & $\begin{array}{l}0 \\
1\end{array}$ & $\begin{array}{l}0 \\
1\end{array}$ & $0.714^{*}$ \\
\hline $\begin{array}{l}\text { Total days of intubation } \\
\text { Median } \\
\text { Interquartile range }\end{array}$ & $\begin{array}{c}2 \\
13\end{array}$ & $\begin{array}{l}2 \\
5\end{array}$ & $0.648^{*}$ \\
\hline $\begin{array}{l}\text { Days of stay in NICU } \\
\text { Median } \\
\text { Interquartile range }\end{array}$ & $\begin{array}{c}26.5 \\
68\end{array}$ & $\begin{array}{c}13.5 \\
35\end{array}$ & $0.094^{*}$ \\
\hline Mortality & $3(10.7 \%)$ & $28(19.1 \%)$ & $\begin{array}{c}0.284^{* *} \\
\text { OR: } 0.5(95 \% \text { Cl } 0.1-1.8)\end{array}$ \\
\hline
\end{tabular}

${ }^{*}$ Mann-Whitney's U test. ${ }^{* *} \chi^{2}$ (or Fisher's exact test if values $<5$ )

$\mathrm{Cl}$, confidence interval; NICU, neonatal intensive care unit; OR, odds ratio; UE, unplanned extubations.

final model with statistical significance (OR 3.1; 95\% Cl 1.3-7.2). After analyzing several possible interactions by stratification, sedation appeared as a modifying factor with an essential effect on birth weight: $<1500 \mathrm{~g}$ with sedation, OR 1.1 (95\% Cl 0.1-10.8), and < $1500 \mathrm{~g}$ without sedation, OR 3.4 (95\% Cl 1.2-9.3); Mantel-Haenszel OR estimate $2.8(95 \% \mathrm{Cl} 1.1-7.0)$ (Table 4).

\section{Discussion}

UEs are a relatively frequent adverse event in NICUs with short-, medium- and long-term clinical effects on the patient. Undoubtedly, an UE is one of the most critical issues in the safety surveillance of neonatal critical care environments because of its frequency, medical consequences, and economic effects ${ }^{8}$. In an excellent study, Kandil et al. ${ }^{2}$ outlined the problem and possible solutions, giving particular importance to studying the characteristics of the incident cases. It is important to use concrete and internationally accepted definitions when classifying UEs to achieve this goal. Otherwise, the number of cases could be underestimated ${ }^{10}$.

Some factors make an UE a significant problem in the NICU. The difficulty of fixing endotracheal tubes to neonates' small faces, the short length of the trachea, not using isolation balloons in the tubes, or the low sedation rate in large ventilated preterm infants are contributing factors highlighted in the published series ${ }^{6}$. 
Table 4. Interaction between weight $<1500 \mathrm{~g}$, sedation, and unplanned extubation

\begin{tabular}{|c|c|c|c|c|}
\hline & & $\begin{array}{l}\text { Neonates } \\
\text { with UE } \\
\text { (28 cases) }\end{array}$ & $\begin{array}{l}\text { Neonates } \\
\text { with no UE } \\
\text { (146 cases) }\end{array}$ & $\begin{array}{c}p \text {-values } \\
\text { and } \\
\text { OR ( } 95 \% \mathrm{CI})\end{array}$ \\
\hline Sedation & $\begin{array}{l}\text { Weight } \\
<1500 \mathrm{~g} \\
\text { Yes } \\
\text { No }\end{array}$ & $\begin{array}{l}1 \\
4\end{array}$ & $\begin{array}{c}9 \\
39\end{array}$ & $\begin{array}{c}0.946 \\
\text { OR: } 1.1 \\
(0.1-10.8)\end{array}$ \\
\hline $\begin{array}{l}\text { No } \\
\text { sedation }\end{array}$ & $\begin{array}{l}\text { Weight } \\
<1500 \mathrm{~g} \\
\text { Yes } \\
\text { No }\end{array}$ & $\begin{array}{c}17 \\
6\end{array}$ & $\begin{array}{l}44 \\
53\end{array}$ & $\begin{array}{c}0.014 \\
\text { OR: } 3.4 \\
(1.2-9.3)\end{array}$ \\
\hline
\end{tabular}

Mantel-Haenszel estimation OR 2.8 (CI 95\% 1.1-7.0).

$\mathrm{Cl}$, confidence interval; $\mathrm{OR}$, odds ratio; $\mathrm{UE}$, unplanned extubations.

In recent years, the intubation route used in our department has been oral due to the problems of nasal septal necrosis that had occurred previously in cases of nasal intubation. The nasal route was possibly more stable and with a lower UE risk, but it is currently becoming rare in these patients.

In our center, we use the fixation system NeoBar Tube Holder (NeoTech Products LLC) with different sizes according to the size of the neonate. The endotracheal tube is fixed to the vertical pole, and a control chest X-ray is always performed to check the position of the tube tip in the trachea. During the five years of the study, the intubation and fixation technique was always the same. We still do not use ultrasound, although exhaled carbon dioxide monitoring is usually maintained.

Awareness programs to reduce the UE frequency exist, although they are not always as effective as desired $^{6,9,11}$. However, based on the actual situation in the NICU, it is the first step to undertake a staff training program and case discussion to decrease the incidence of these adverse events. Analyzing the UE causes and proposing solutions with a plan of action and within an evidence-based prevention environment is the next step before a further audit to measure improvement ${ }^{4,12}$.

Some authors propose a goal of less than 1 UE per 100 days of invasive mechanical ventilation ${ }^{13}$. Undoubtedly, the use of checklists with an evaluation of endotracheal tubes could be an essential factor in improving UE rates ${ }^{14}$.

Our rates have been improving progressively in recent years, although we should not be overly optimistic. We will have to wait and see what happens in the future; the average figure for these five years is situated among the averages reported in other publications ${ }^{11}$. Although this improvement is not related to a single cause, it can be explained by a continuous progress in the care and safety measures.

Data showed that the youngest neonates are the most likely to extubate spontaneously. However, weight (but not gestational age) was the determining factor in the UE risk in the multivariate analysis, perhaps due to other concomitant factors, such as the sample's distribution.

Besides weight, our series highlights the importance of sedation, which appears as an effect modifying variable on weight (Table 4): the lower use of sedation/ analgesia in the smallest patients could be a conditioning factor in making weight the most important factor.

Sedation/analgesia during mechanical ventilation in premature neonates is one of the most critical issues. Our sedation percentages are excessively low, although they have been progressively increasing in recent years. In any case, establishing a staff training program in the safety of intubated patients and the development of checklists seem mandatory to control this problem.

More than half of our newborns did not require re-intubation, which is also an interesting fact related to the current policy of all neonatal units to reduce invasive mechanical ventilation times, trying to use non-invasive ventilation to save days of intubation.

Important short-, medium-, and long-term clinical consequences of UEs have been described ${ }^{15}$. The medium- to long-term effects of UEs on the evolution of the patients regarding respiratory or neurological outcomes was not the subject of this study and remains open to future analysis; however, we found no differences between neonates with and with no UEs regarding NICU stay and mortality (Table 2).

Our study is a single-center study, with retrospective data from five years, which are limitations of this type of study, especially due to the number of cases. However, its strength lies in the fact that our unit could represent a very high percentage of regional, Spanish, and Latin American reference NICUs, with their advantages and disadvantages. Also, the value of the data lies in the strict collection of episodes that are mandatorily described in the electronic medical records, which prevents underreporting.

UEs are a relatively frequent problem in our environment, with an average rate in the last 5 years of 2.93 cases per 100 days of invasive ventilation, although decreasing in recent years. The birth weight under 
$1500 \mathrm{~g}$ and the absence of sedation are factors related to this critical safety problem.

\section{Ethical disclosures}

Protection of human and animal subjects. The authors declare that no experiments were performed on humans or animals for this study.

Confidentiality of data. The authors declare that they have followed the protocols of their work center on the publication of patient data.

Right to privacy and informed consent. The authors have obtained the written informed consent of the patients or subjects mentioned in the article. The corresponding author has this document.

\section{Conflicts of interest}

The authors declare no conflict of interest.

\section{Funding}

None.

\section{References}

1. Panagos PG, Pearlman SA. Creating a highly reliable neonatal intensive care unit through safer systems of care. Clin Perinatol. 2017;44:645-62.
2. Kandil SB, Emerson BL, Hooper M, Ciaburri R, Bruno C, Cummins N et al. Reducing unplanned extubations across a children's hospital using quality improvement methods. Pediatr Qual Saf. 2018;3:e114.

3. Torres-Castro C Valle-Leal J, Martínez-Limón AJ, Lastra-Jiménez Z, Delgado-Bojórquez LC. Complicaciones pulmonares asociadas a ventilación mecánica en el paciente neonatal. Bol Med Hosp Infant Mex. 2016;73:318-24.

4. Hu X, Zhang $Y$, Cao $Y$, Huang G, Hu Y, McArthur A. Prevention of neonatal unplanned extubations in the neonatal intensive care unit: a best practice implementation project. JBI Database System Rev Implement Rep. 2017:15:2789-98.

5. Meregalli CN, Jorro-Barón FA, D’Alessandro MA, Danzi EP, Debaisi GE. Impacto de una intervención de mejora de calidad sobre la incidencia de extubaciones no planeadas en una unidad de cuidados intensivos pediátricos. Arch Argent Pediatr. 2013;111:391-7.

6. Utrera-Torres MI, Moral-Pumarega MT, García-Lara NR, Melgar-Bonís A, Frías-García ME, Pallás-Alonso CR. Frecuencia de extubaciones no programadas en una unidad de cuidados intensivos neonatales. Estudio antes y después. An Pediatr (Barc). 2014;80:304-9.

7. Da Silva PS, Reis ME, Aguiar VE, Fonseca MC. Unplanned extubation in neonatal intensive care unit: a systematic review, critical appraisal and evidence-based recommendations. Respir Care. 2013;58:1237-45.

8. Hatch LD $3^{\text {rd }}$, Scott TA, Slaughter JC, Xu M, Smith AH, Stark AR, et al. Outcomes, resource use, and financial costs of unplanned extubations in preterm infants. Pediatrics. 2020;145:e20192819.

9. Klugman D, Melton K, Maynord PO, Dawson A, Madhavan G, Lee Montgomery $\mathrm{V}$, et al. Assessment of an unplanned extubation bundle to reduce unplanned extubations in critically ill neonates, infants, and children. JAMA Pediatr. 2020;174:e200268.

10. Mbi Ndakor S, Nelson MU, Pinheiro JMB. Counting unplanned extubations: marked variation among neonatologists. J Perinatol. 2017;37:698-701.

11. Ferraz P, Barros M, Miyoshi M, Davidson J, Guinsburg R. Bundle to reduce unplanned extubation in a neonatal intensive care unit. $J$ Matern Fetal Neonatal Med. 2020;33:3077-85.

12. Nair V, Smith $\mathrm{H}$. Phased quality improvement interventions in reducing unplanned extubation in the neonatal ICU. Respir Care. 2020;65:1511-8.

13. Merkel L, Beers K, Lewis M, Stauffer J, Mujsce DJ, Kresch MJ. Reducing unplanned extubations in the NICU. Pediatrics. 2014;133:e1367-72.

14. Concha-Torre A, Díaz-Alonso A, Álvarez-Blanco S, Vivanco-Allende A, Mayordomo-Colunga J. Fernández-Barrio B. Las listas de verificación: ¿una ayuda o una molestia? An Peditr. 2020;93:135.e1-135.e10.

15. Kambestad KK, Huack A, Nair S, Chapman R, Chin S, Langga L, et al. The adverse impact of unplanned extubation in a cohort of critically ill neonates. Respir Care. 2019;64:1500-7. 